\title{
How the Communal Buildings Created? \\ Socio-Spatial Transformation of the Osing in Kemiren Village towards Social Sustainability
}

\author{
I Made Dwiki Putrawan', Ni Ketut Agusintadewi ${ }^{2}{ }^{*}$, and Widiastuti ${ }^{3}$ \\ 1,3 Master of Architecture Program, Universitas Udayana, Indonesia. \\ ${ }^{2}$ Human Settlements and Ethnic Architecture Studies, Universitas Udayana, Indonesia. \\ Corresponding Author: nkadewi@unud.ac.id
}

\begin{tabular}{|c|c|}
\hline & Abstract \\
\hline $\begin{array}{l}\text { Keywords: } \\
\text { Communal } \\
\text { building, Socio- } \\
\text { spatial } \\
\text { transformation, } \\
\text { Social } \\
\text { sustainability, the } \\
\text { Osing, } \\
\text { Traditional } \\
\text { houses }\end{array}$ & $\begin{array}{l}\text { The socio-cultural life of the Osing in Kemiren Village always } \\
\text { interplays with their social activities and interactions, both among } \\
\text { local people and travellers who come to visit the village. To } \\
\text { accommodate these various activities, the Osing uses communal } \\
\text { buildings, such as the Pesantogan Kemangi and two cultural houses: } \\
\text { the Sukosari and the Osing. Data from the field reveals that the } \\
\text { traditional house is a reference for creating communal buildings. The } \\
\text { study aims to disclose the transformation process in spatial patterns } \\
\text { and forms that occurs in communal facilities. It discusses a set of } \\
\text { combination parts of traditional houses that create communal } \\
\text { buildings. A qualitative inquiry was carried out the study with } \\
\text { ethnography approach. The result shows that socio-spatial } \\
\text { transformation occurs in a dynamic change of communal activities } \\
\text { that affect new architectural models of the public buildings. The } \\
\text { transformation includes dimensional spatial patterns and building } \\
\text { shapes, reduction, and additional spaces and components. Finally, the } \\
\text { study contributes to being a reference for future research in the } \\
\text { traditional architecture of the Osing. Both the local government and } \\
\text { people work organised in preserving traditional architectural values as } \\
\text { a pearl of local wisdom. Therefore, it supports and encourages tourism } \\
\text { programs in Kemiren Village towards a socially sustainable } \\
\text { community. }\end{array}$ \\
\hline $\begin{array}{l}\text { DOI: } \\
\text { @ } 2017 \text { The Authors. I }\end{array}$ & $\begin{array}{ll} & \text { Article } \\
\text { iblished by GKAK UNMER Malang } & \text { History }\end{array}$ \\
\hline
\end{tabular}

\section{INTRODUCTION}

In social life, humans need to interact in their environment for the sake of cooperation. Social interaction can be defined as dynamic social relationships. Walgito (2003) states that social interaction is a relationship between one individual and another. This interaction that occurs is a culture due to it contains a language process. People use specific local languages and organise formal and informal associations. Maintaining social 
interactions becomes essential, considering that socio-cultural interaction is starting to diminish slightly. The interaction pattern changes due to the presence of gadgets at all level of the people. Togetherness values are increasingly lost due to humans' high dependence on technology (Tamariska and Ekomadyo,2016).

The existence of communal space is necessary for the community to interact, thus encouraging people to meet up and carry out social interactions. Even Shaftoe (2012) emphasise that communal space can arouse residents' desire to be one community. The function of communal space is as a forum for social interaction, which accommodates the need to meet, interact, and do joint activities (Tamariska et al.,2017; Darmiwati,2000). In the context of an area's social sustainability, a representative communal space indicates virtuous human interactions, good communication, and cultural development (Yiftachel and Hedgcock,1993). In sustainability circles, social sustainability is one aspect of sustainable development (James,2015). With social sustainability, an area's physical infrastructure and social life can go hand in hand to provide social spaces for the community. These social spaces can accommodate the community to develop, form groups and accommodate children who are the next generation to grow well. Therefore, social sustainability during the community is significant to consider for a better future.

The existence of communal space in an area cannot be separated from the dynamics of society's socio-spatial transformation. In the transformation process, socio-spatial relations can be a dynamic process of changes in the economic, political, and sociocultural situation that interplays with spatial aspects (Widyastuti,2013; Cassiers and Kesteloot,2012). Spatial relations can be formed from activities carried out by humans, both interpersonal and social associations, either in a cultural or regional context. In the case of this study, socio-spatial relations are a relevant issue to discuss. The Osing tribe (as mentioned as the Osing) is one of Indonesia's tribes whose socio-spatial conditions are slowly transforming according to the environment and society's needs.

The Osing is an indigenous ethnic group of Kemiren Village in Glagah District, Banyuwangi. In social life, the tribe is inseparable from social activities, such as gathering and doing cultural and social activities among communities. As a social interaction place, the local community used residents' house alternately to gather and meet. With Kemiren Village's designation as a tourist village since 1995, the need for communal space is increased. In this condition, several communal buildings were built for interpersonal and social interactions between the local community and tourists. For these activities, the local community uses several communal facilities, namely the Pesantogan Kemangi and both cultural houses: the Osing and the Sukosari.

The existing communal buildings in Kemiren Village connect with the traditional houses referred for communal facilities order. Furthermore, the facility is modified to its capacity, activity, and community. Adjustments to community life dynamics, interaction with outside cultures, and modern architecture have transformed traditional architecture, forming communal buildings for the Osing in Kemiren Village. The socio-spatial transformation can take the form of addition or subtraction, determining whether the original form of traditional architecture can be preserved.

According to previous studies, only a few kinds of research discuss the relationship between traditional houses and communal buildings of the Osing. It can be said; the study is an essential topic to be explored. When local people design a new public building, the design can implement some traditional houses' references. It means the local people can preserve some values from traditional architecture. Even though it has 
similarities with the traditional houses, each building in Kemiren Village has a spatial pattern and various building forms.

From the above, some questions can be explored. How can activities and capacity order spatial layout and physical elements of traditional houses and communal buildings? How traditional houses changed into an architectural model in the form of communal buildings? How does socio-spatial transformation affect this change towards social sustainability? The questions need to be answered.

The study aims to reveal activities and capacity order spatial layout and physical elements in traditional houses that changed within communal buildings because of their capacity by local communities and tourists to gather and carry out socio-cultural activities. The criteria for selecting samples refers to the authenticity of the building form and suggestion from local people. Therefore, the study can further offer traditional architecture to tourists and encourage the tourism village programs in Kemiren Village. Besides that, the communal buildings' valuable existence that accommodates social interactions, both personal and interpersonal, can reflect the dwellers' good social life to live in social sustainability, as suggested by sustainable development concepts.

\section{RESEARCH METHODS}

\section{Research Strategy}

The study aims to identify and explore the communal building's transformation in Kemiren Village, which is caused by the local community's socio-spatial conditions, as an effort to support social sustainability. According to research objectives, the study was approached by a qualitative inquiry that was used to explore the natural phenomena (Creswell,2009); in this context, it is the spatial layout and transformation in communal buildings of the Osing. Besides that, qualitative methods can be used to research problems related to society's socio-cultural conditions (Bahar,2019). Meanwhile, the ethnographic approach was chosen because it focuses on a specific ethnic group in a limited area (Cresswell,2007): the Osing in Kemiren Village. The data collection process is carried out with an ethnographic approach, an approach to collecting data following existing conditions in the field (Setyabudi,2021) and making the relevant matters more evident in the study's context. The ethnographic approach is applied by direct observation of the similarity patterns in traditional house buildings and communal buildings.

\section{Collecting Data}

Fieldwork was conducted before the global pandemic of Covid-19 in several visits. Researchers observed and participated directly in community activities. Additionally, indepth interviews were also conducted with parties who have important roles, such as the former village head, regarding the condition of the existing communal buildings and the basic patterns of the traditional houses of the Osing. The community also supported this study by providing suggestions on which buildings should be used as communal spaces. Therefore, purposive sampling was used to explore related data. Table 1 describes the linkage between themes and research variables within the field survey activities. 
Table 1. Themes and variables within the field survey approach

\begin{tabular}{lll}
\hline Themes & Variables & $\begin{array}{l}\text { Fieldwork } \\
\text { activities }\end{array}$ \\
\hline Spatial order & $\begin{array}{l}\text { Traditional houses: spatial layout, room } \\
\text { functions, domestic activities } \\
\text { Communal buildings: spatial layout, room } \\
\text { functions }\end{array}$ & $\begin{array}{l}\text { Physical } \\
\text { observation, } \\
\text { physical mapping, } \\
\text { photographic } \\
\text { records, interviews }\end{array}$ \\
Physical order & $\begin{array}{l}\text { Building structure and constructions, local } \\
\text { modules and form, building facades }\end{array}$ & \\
Socio-spatial order & $\begin{array}{l}\text { Cultural activities, local activities, socio- } \\
\text { spatial transformation }\end{array}$ &
\end{tabular}

Source: formulated from a theoretical framework, 2020

\section{Analysis and Interpretation of Data}

The ethnographic strategy focuses on the entire order of the Osing buildings, both houses and communal spaces, as a cultural group. This strategy describes and interprets the shared and learned patterns of the buildings' spatial and physical order and sociospatial relations ordered by cultural and local activities and its transformation as a culture-sharing group. Linkages, insights, and connections are analysed from the field data and associated with the study's purpose and objectives. Then, it was possible to answer how questions satisfactorily. As for the structural analysis, this study uses sociospatial relations to identify a link between spatial and physical order in traditional houses and communal buildings and socio-cultural situation within the transformation towards social sustainability.

Some viewpoints on socio-spatial relations and their transformation analysed all the obtained data. Engagement between findings from the field and appropriate approaches is to reveal the phenomenon. Finally, a conclusion could be made through the induction viewpoint.

\section{RESULTS AND DISCUSSION}

\section{Traditional Osing Houses}

Tradition is an activity that is practised and inherited over generations (Harpioza,2016), so it is also considered a successful cultural product, including architectural products. Traditional architecture is a part of people's lives that has a remarkable value and attached to people's practices. Traditional Osing houses have movable house characteristics. This condition was because this tribe had to move around to adapt to their enemies' attack while under the Blambangan Kingdom's reign (Sukatman,2016). The house's basic form has no spatial hierarchies that reflect social structures, similar to the kampung (Javanese) house. Compared to Javanese culture, the traditional home of the Osing has different names and simpler forms of construction.

Suprijanto (2002) discloses that a traditional Osing house's spatial pattern is always presented by bale, jrumah, and pawon. Each room has a different function. Bale, which locates at the front, functions as a living room, family room, and ceremonial space. Jrumah is situated in the middle of the house and served as a private room and bedroom, while pawon is a kitchen, informal living room, and family room. Apart from these spaces, 
house activities also accommodated by supporting domestic spaces: amper (a veranda), ampok, pendopo (a pavilion) and lumbung (a granary), but it is an optional domestic facility. The people believe in a centrality concept, which is reflected in the three main rooms (bale, jrumah, and pawon) as the centre of house unity. In contrast, the supporting rooms (amper, ampok, and house yard) are territorial and identity symbols of this tribe. It can be seen in Figure 1.

The house's basic form has no spatial hierarchies that reflect social structures, similar to the kampung (Javanese) house. Compared to Javanese culture, the traditional home of the Osing has different names and simpler forms of construction. Three indicators of these basic shapes are the roofs of tikel balung, baresan, and cerocogan, with facades that tend to be symmetrical. Cerocogan is the basic module of space. When a complement part is added to the roof, it becomes a baresan. Then, a double part added is mentioned as a tikel balung, as shown in Figure 2.

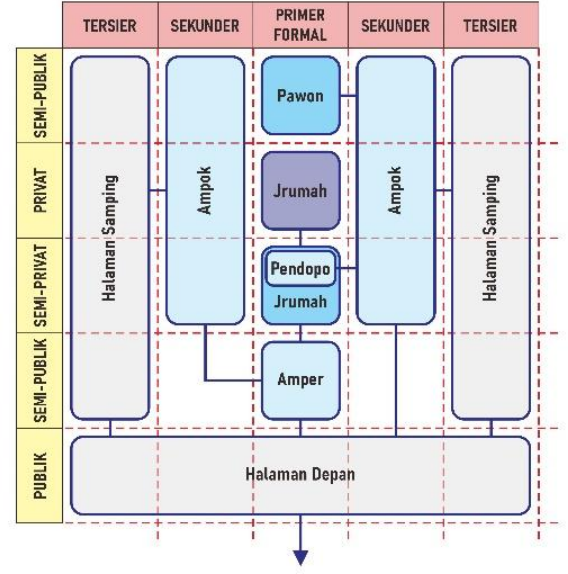

Figure 1. Spatial pattern of traditional house of the Osing Source: redrawn from

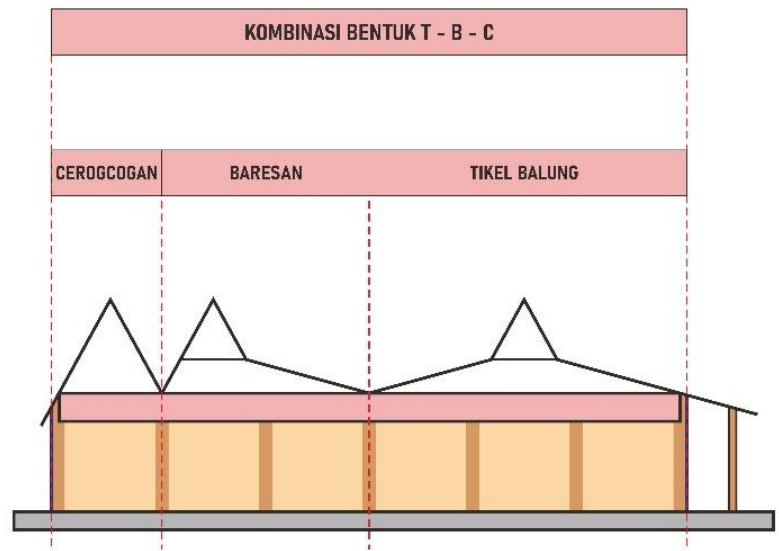

Figure 2. Roof construction classify house typo-morphology

Source: redrawn from Suprijanto, 2002

Table 2 describes a variety of house form, as discussed above. Extra rooftops are needed to accommodate the need for space. It means roof construction specifies house typo-morphology, along with its shape (Suprijanto,2002).

Table 2. A variety of house form

\begin{tabular}{cl}
\hline Amount of house parts & Combination of house part \\
\hline 3 & Tikel Balung - Tikel Balung - Cerogcogan \\
& Tikel Balung - Baresan - Cerogcogan \\
& Tikel Balung - Cerogcogan - Cerogcogan \\
& Tikel Balung - Cerogcogan - Tikel Balung \\
& Tikel Balung - Tikel Balung \\
& Tikel Balung - Baresan \\
& Tikel Balung - Cerogcogan \\
& Tikel Balung \\
& Cerogcogan \\
\hline
\end{tabular}

Source: Suprijanto, 2002 


\section{Communal Buildings}

The communal buildings that were investigated are the buildings that accommodate socio-cultural activities and interactions between the Osing and tourists. According to the building's authenticity aspect, the uniqueness, and recommendations from the local people, these buildings are Pesantogan Kemangi and two cultural houses: the Sukosari and the Osing. Each building has several differences in spatial pattern and building shape. Figure 3 shows the locates of the communal facilities in Kemiren Village.

Pesantogan Kemangi is the first building that tourists usually visit, either just stopping by, travelling, or having a particular purpose in Kemiren Village. The building provides an art shop, a coffee shop, and a helpdesk for tourist information. Several facilities in that building make the spatial pattern applying a compound system, see Figure 5. Meanwhile, Figure 4 illustrates a coffee shop that is a part of tourist services in Pesantogan Kemangi. Spatial patterns reflect an open plan concept with both facilities: a stage and a seating area. As a result, the building has no partition that separates the above facilities and house yard, making a bigger capacity. Besides that, a tikel balung which consists of three space modules, creates the building appearance. It looks like a tikel balung, or a traditional house with three space modules. However, the difference is several spaces and their position in the housing module. A seating area is in the front and the middle and the stage at the rear, as Figure 6 illustrated.
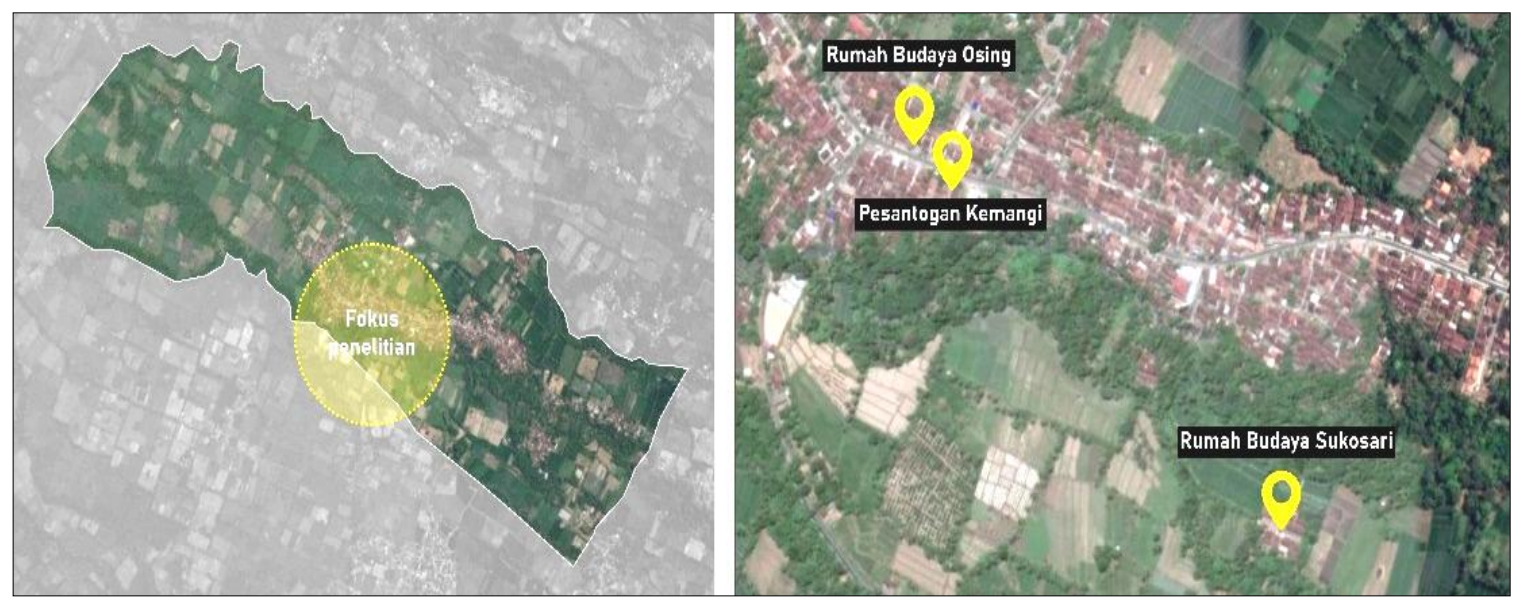

Figure 3. The pinpoints of communal buildings in Kemiren Village Source: modified from the images of Google Maps, October 2020

The Sukosari Cultural House (as mentioned as the Sukosari) locates in Sukosari, a part area of Kemiren Village. Apart from being a place for welcoming and gathering simultaneously, the Sukosari is also a tourist destination due to the government established it as a cultural heritage area. It aims to preserve the authenticity of the Osing in Kemiren Village. Figure 7 illustrates that the building has a larger capacity than Pesantogan Kemangi and consists of two tikel balung made into one mass-building with an additional ampok on the left. 


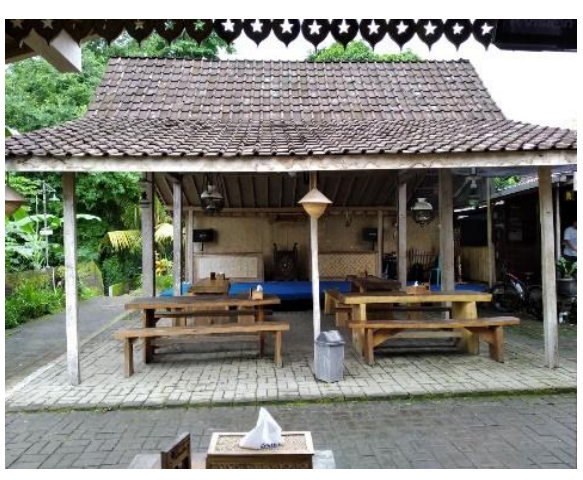

Figure 4. The Pesantogan Kemangi communal building

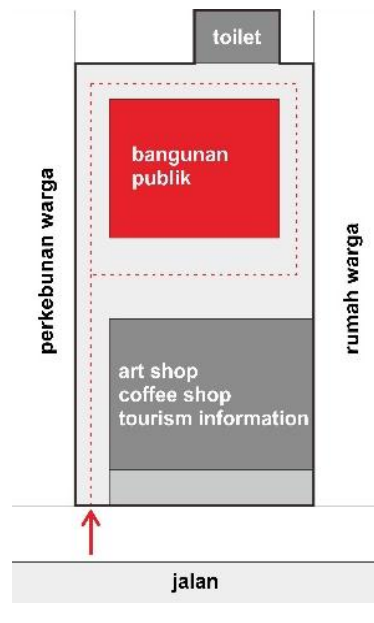

Figure 5. A compound system of the building mass

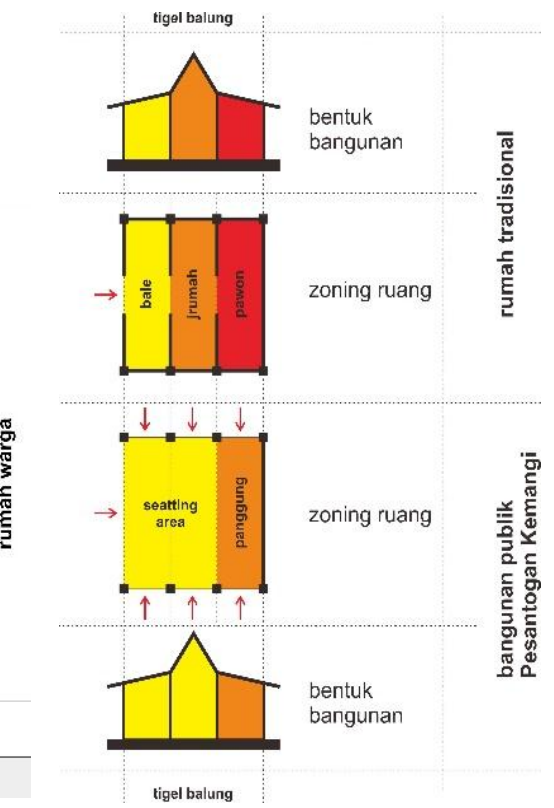

Figure 6. Spatial pattern and building form in comparison to traditional house

Furthermore, the cultural house is divided into a seating area, an indoor stage, and storage. The open space concept is also applied in the seating area and the indoor setting. The warehouse is closed and store pieces of performance equipment. Two sets of tigel balung construct the Sukosari and are combined another tigel balung. As a result, the building construction is a tigel balung-tigel balung, as described in Arrangement 5 in Table 1. An ampok is positioned on one side of the building. It can be said; the Sukosari has a similar spatial pattern with the traditional house, which consists of three main parts. However, it has a different function in space: the seating area (at the front and side part/ampok), the stage (in the middle), and storage (at rear), as shown in Figure 8.

Figure 9 shows another communal building, the Osing Cultural House, located in the village's centre. The cultural house has a particular function, such as serving a dining procession to visitors or tourists with a local culinary menu of pecel pithik (a traditional peanuts salad). For this reason, the building is modified in a slight spatial pattern with an open plan concept. A pawon (kitchen) is positioned at the back of the building. The cultural house also consists of several buildings that are merged into one mass. Therefore, the cultural house appears a combination of three groups: tigel balung-tigel balungcerogcogan, as described in Arrangement 1 in Table 1. The building's spatial pattern has a similar organisation to the traditional house, particularly in terms of number and function. The seating area is in the front, the middle part is the stage, and pawon is arranged at the back. It can be illustrated in Figure 10. 


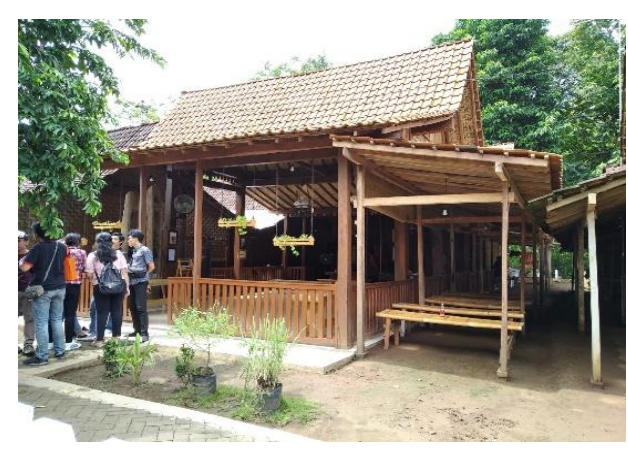

Figure 7. The Sukosari cultural house

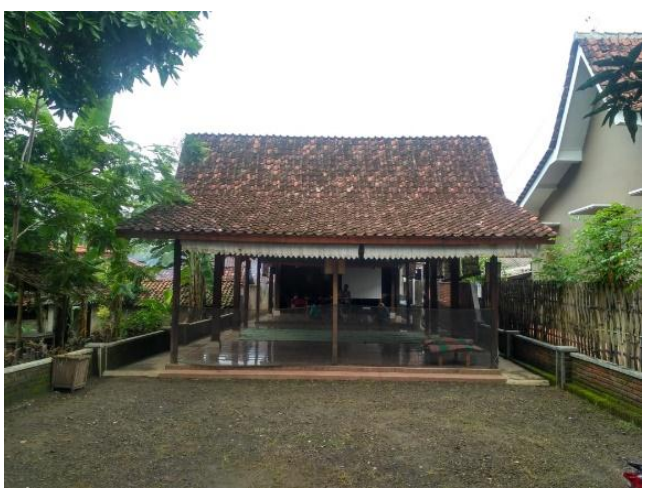

Figure 9. The Osing cultural house

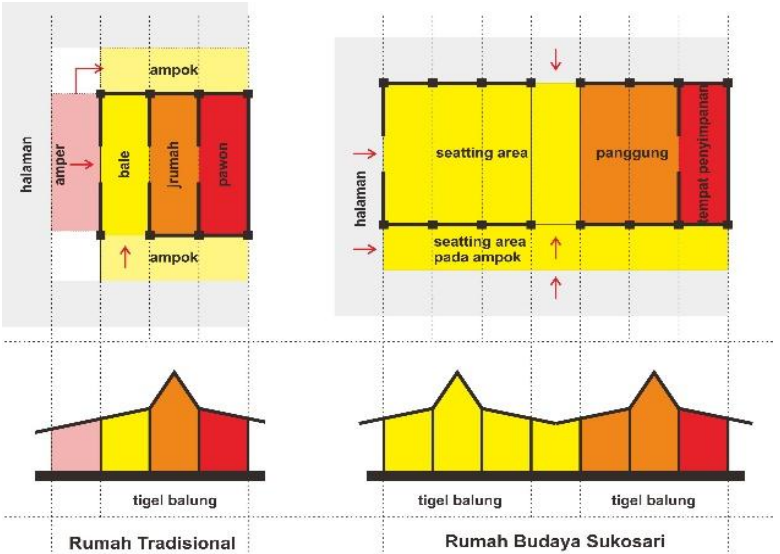

Figure 8. Spatial pattern and building form in comparison to traditional house

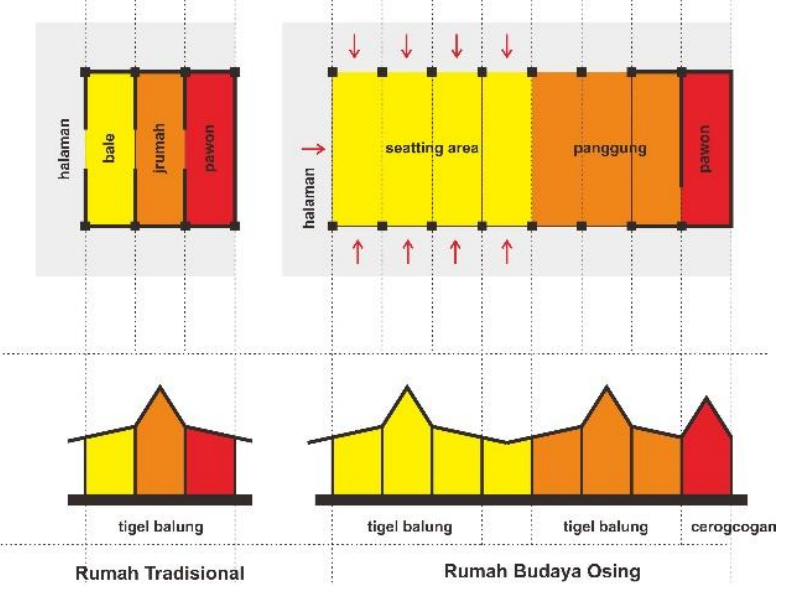

Figure 10. Spatial pattern and building form in comparison to traditional house

Figure 11 shows the comparison of the building forms of each communal building and the traditional house. From the model, it is known that the front is a public sphere, but in the place, it is a living room (bale), while in communal buildings, it is a seating area for social gathering. A semi-public sphere in a house is jrumah or a room, whereas it is a building stage. As a private area of the house, the rear is pawon (kitchen); another facility is storage.

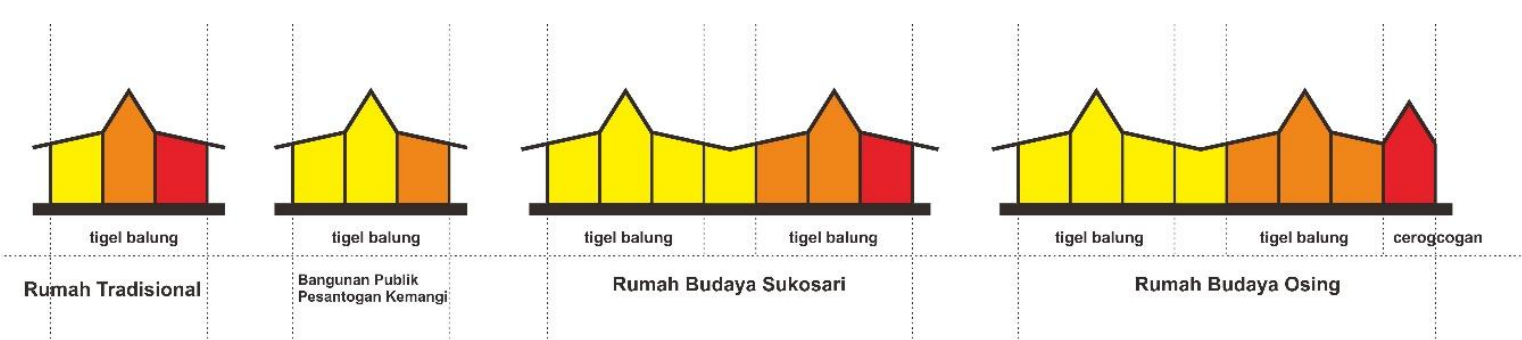

Figure 11. The comparisons of the building forms: communal and traditional house 


\section{Socio-Spatial Transformation towards Social Sustainability}

Social interactions among the Osing and tourists are dynamic relations, and it is a reciprocal relationship. Here, communal buildings are necessary for the community to interact, accommodating the need to meet up and do joint activities. These buildings cannot be fully understood without the Osing and tourists' relationship, actions, and minds. It is one of the basic needs of the Osing to develop their social lives and arouse their desire to be one community, as Shaftoe (2012) and Carmona (2008) emphasised.

A socio-spatial transformation in the Osing in Kemiren Village after establishing as the tourism village was a fundamental change in communal activities. It consequently affects changing spatial needs. Today, the Osing live permanently, so the people need a space to accommodate community activities for gathering and socialising. Initially, these activities were only conducted in one of the residents' houses. With the establishment of Kemiren as a tourist village, those activities are also carried out with tourists. The sociospatial transformation has created an architectural model in the form of communal buildings. However, the traditional house is still a guidance for an architectural model after adjusting to the activities they contain. It can be said; socio-spatial transformation in Kemiren Village is a dynamic process of changes in the socio-cultural situation that interplays with spatial aspects, as Widyastuti (2013) and Cassiers and Kesteloot (2012) stated.

According to the above, the socio-spatial transformation includes changes in the whole existing size, both spatial and building. The communal building organises a seating area, a stage, and additional space: storage and kitchen. Changes in spatial dimensions commonly occur in the seating area and stage due to accommodating activities and capacity, and finally, it changes building size. The bigger capacity and number of spaces functioned, the larger the building size. As a result, building combinations, such as tigel balung-tigel balung (the Sukosari Cultural House) and tigel balung-tigel balung-cerogcogan (the Osing Cultural House).

Secondly, subtractive changes that occur in communal buildings appear the reduction of space occupied and its elements. On the other hand, some domestic spheres in traditional houses also transformed into a seating area and a stage, with two optional extra rooms: storage and kitchen. An open plan system applied in the communal building reduces spatial elements that affect building appearance. Even though it still adopts the basic form, the minor partition used gives an image that the building is more open, friendly, and cosy than a traditional house. And finally, additive changes relate to the dimensional part. Building configuration initially displays the local house's basic shape: cerogcogan, baresan, and tigel balung. A form change in architectural transformation occurs after experiencing dimensional change, reduction, and additional parts from the field. It fully supports Bacon's (1974) viewpoints. Thus, traditional buildings' spatial layout is physically and non-physically elaborated to reference the current architectural form (Lake et al., 2020).

Furthermore, referring to a week-scale, intensity in the Pesantogan Kemangi is the highest due to its strategic position in the village's centre. Besides that, the communal building that provides a coffee shop, an art shop, and tourist information is always crowded along days. Local people and tourists interact in many activities, such as gathering, having coffee time, or just chatting. On the other hand, other cultural houses have a lower intensity. The Sukosari only opens daily to serve tourists and inaccessible, so people need extra time to reach. Even though the Osing Cultural House locates in the inner village, a few activities can be done. This cultural house is only used to serve 
tourists and visitor on a specific schedule. Therefore, accessibility and strategic location are essential aspects of elected communal space. Good accessibility encourages collaborative space by an assortment of people with high frequency, as Parkinson (2012) and Carmona et al. (2008) perspectives.

Above all, it can be explained how communal buildings has a meaning to the Osing. Adequate communal space functioned as a forum for interpersonal and social interaction is an indicator of the Kemiren Village's social sustainability. The village has an excellent capability to provide an appropriate place for human interaction, communication and cultural development. The Osing respects the human rights of the local people and tourists by creating a respectable social life. Providing communal buildings has an essential meaning to indicate sustainability in the social pillar of sustainable development in Kemiren Village. It is relevant to Yiftachel and Hedgcock (1993) opinion.

\section{CONCLUSIONS}

In the socio-spatial transformation process in community activities after the tourism village programme, the traditional house is still a reference for creating the existing communal buildings in Kemiren Village. It is also motivated by tourism activities that make the public buildings function as shared spaces for local people and tourists. The communal areas with high intensity can be seen by taking advantage of these spaces as interaction and communication forums, both personal and interpersonal. Social interaction can be defined as dynamic social relationships

The need for communal space of the Osing emerges social awareness that social interaction is part of daily needs. The social interaction can be done either a formal or an informal borderless, doing at any time, by utilising unplanned spaces or spaces that are relatively close with the dwellers. The dwellers' needs in social interaction need fulfilment to make social contact individually or in groups. Social interaction is the key to social life because, without interaction, it is impossible to live together.

One of the sustainable development pillars is the social aspect of the human dimension that humans live in a circle of local and global communities in interdependent relationships. Social sustainability is marked by a society that respects human rights, including creating a good life through a culture of social interaction. Both planned and unplanned communal activities play an essential role as a means or place to interact. In Kemiren Village, most of the scheduled interactions are created through routine cultural activities for tourism. In contrast, unplanned interactions occur mostly like ordinary orders for residents and tourists to socialise.

Owing to the limited communal buildings in Kemiren Village that were investigated as research samples, the study can be developed through outdoor spaces. Sunday open market that offers various local culinary menus to the dwellers and tourists and a bridal parade of the Osing conducted on specific scheduled are a few outdoor socio-cultural activities. Further research should be carried out with a larger sample to explore the socio-spatial transformation and communal space's role in different settings and characteristics. Thus, a comprehensive conclusion will be drawn about the phenomenon in the social sustainability of the Osing in Kemiren Village. 


\section{REFERENCES}

Bacon, E. (1974) Design of the City, Revised Edition, Viking, New York.

Bahar, Faisal. (2019) “Environmental Characteristics of Fishermen's Settlements as a Form of Local Wisdom of Coastal Communities in Karangsari Village, Tuban" Local Wisdom, 11 (1), 53-66.

Carmona M., Magalhaes S., Hammond L. (2008) Public Space, the Management Dimension, Routledge, Taylor and Francis Group, London and New York,

Cassiers, T. and Kesteloot, C. (2012) "Socio-spatial Inequalities and Social Cohesion in European Cities" Urban Studies, 49(9), 1909-1924.

Creswell, J.W. (2007) Qualitative Inquiry and Research Design: Choosing among Five Approaches, Second Edition, SAGE Publications, Los Angeles.

Creswell, J.W. (2009) Research Design. Qualitative, Quantitative, and Mixed Methods Approaches. SAGE Publications, Los Angeles.

Darmiwati, R. (2000) "Studi Ruang Bersama dalam Rumah Susun bagi Penghuni Berpenghasilan Rendah" Jurnal Dimensi Teknik Arsitektur, 28(2), 114-122.

Harpioza, O.D. (2016) “Identifikasi Perubahan Arsitektur Rumah Tradisional Studi Kasus Permukiman Desa Kurau, Aliran Sungai Desa Kurau di Kabupaten Bangka Tengah, Provinsi Bangka Belitung" Laporan Tesis. Universitas Atma Jaya, Yogyakarta.

James, P. (2015) Urban Sustainability in Theory and Practice: Circles of sustainability, Routledge, New York.

Lake, R.C., Purbadi, Y.D., Harmans, H.F. (2020). "Identification and Orientation on Spatial Arrangement of Wajo Traditional Village, Keo Tengah, Nagekeo Regency" Local Wisdom, 12 (1), 19-30.

Parkinson, J. (2012) Democracy and Public Space, Oxford University Press, Oxford.

Setyabudi I., Santoso D.K., Albina, K. (2021) "Gawai": Cultural Activities in the Shroud of Jangkang Bokidoh Dayak Tribe Traditional Architecture in Balai Sebut Village" Local Wisdom, 13 (1), 36-50.

Shaftoe, H. (2012) Convivial Urban Spaces: Creating Effective Public Places, Earthscan, London.

Sukatman. (2016). Blambangan: Rekonstruksi Identitas Kebangsaan dan Pengembangan Industri Wisata. Penerbit Ombak, Yogyakarta.

Suprijanto, I. (2002) “Rumah Tradisional Osing: Konsep Ruang dan Bentuk" Jurnal Dimensi Teknik Arsitektur, 30(1), 10-20.

Tamariska, S.R. and Ekomadyo, A. (2016) "Place-making' Wadah Interaksi Sosial Kampung Kota" Prosiding Seminar Nasional Kearifan Lokal, Departemen Arsitektur USU, Medan.

Tamariska, S.T. et al. (2017) “Peran Ruang Komunal terhadap Keberlanjutan Sosial: Studi Komparasi Perumahan Terencana dan Perumahan Tidak Terencana (Perumahan Sukaluyu Dan Kampung Tubagus Ismail Bawah)" Prosiding Seminar Nasional Kearifan Lokal dalam Keberagaman untuk Pembangunan Indonesia, 285-292, Departemen Arsitektur, Fakultas Teknik, Universitas Sumatera Utara, Medan. 
Walgito, B. (2003) Pengantar Psikologi Umum, Andi Offset, Yogyakarta.

Widyastuti, D. (2013) “Transformation of Public Space: Social and Spatial Changes A Case Study of Yogyakarta Special Province, Indonesia" Doctoral Dissertation, University of Dortmund (TU Dortmund), Dortmund Germany.

Yiftachel, O. and Hedgcock, D. (1993) "Urban Social Sustainability: The Planning of an Australian City" Cities, 10, 139-157. 